\title{
Botanical Collections in the Black Lake Region of Northern Saskatchewan (1960)
}

by George W. Scotter, Canadian Wildlife Service, Edmonton

The author spent the field season of 1960 in the Black Lake region of northern Saskatchewan studying the effects of fire on the winter range of the barren-ground caribou (Rangifer arcticus). This project was sponsored by the Canadian Wildlife Service of the Department of Northern Affairs and Niatural Resources. Special emphasis was placed on botanical investigations such as plant succession following forest fires and on the carrying capacities of range plants.

The study area was located in the Black Lake region of northern Saskatchewan. It extended from $59^{\circ} \mathrm{N}$. to $60^{\circ} \mathrm{N}$. latitude and from $104^{\circ} \mathrm{W}$. to $106^{\circ} \mathrm{W}$. longitude. The localities from which specimens were collected are:

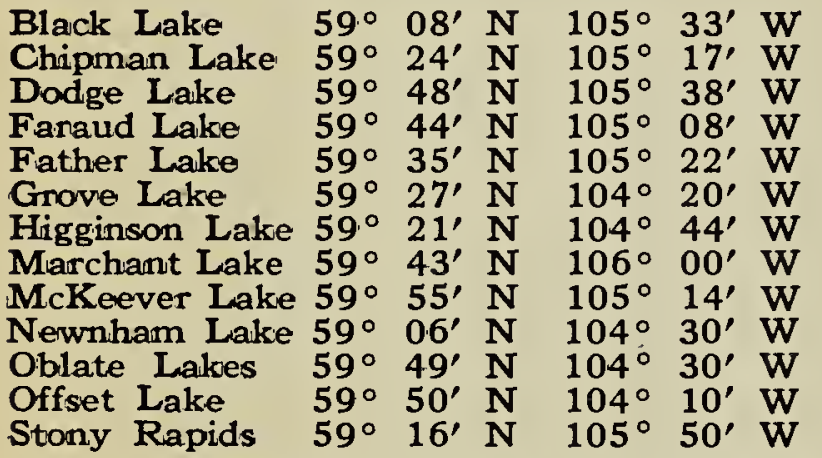

No comprehensive botanical exploration has been carried out in this area previously and a number of the species collected represent new records or north or northeastern range extensions for the province of Saskatchewan. The plants collected by H. M. Raup (1936) in the Lake Athabaska region form the only large collection reported from northern Saskatchewan. The collection reported here is east of the region visited by Raup. With the exceptions of scattered collections by Preble (1908) and Tyrrell (1908), the flora in this region appears to be unknown botanically. This list, therefore, will add to our knowledge of the provincial flora.

"An Annotated List of the Plants of Saskatchewan," prepared by Fraser et al. (1954) was useful in determining plant distribution, as was the "Annotated Catalogue of Vascular Flora of Saskatchewan," published by Breitung (1957). Both publications depended almost entirely on Raup's work for plant records in this region of Saskatchewan.

The geology of the area is discussed in a paper prepared by Alcock (1936). North of the Fond du Lac River and Black Lake the rocks are an old Precambrian metamorphic assemblage. The rocks are considerably folded and faulted and are variable over relatively short distances. South of this area the rock is predominantly Athabasca sandstone of a later Precambrian age. It is uniform over considerable distances and is relatively unfolded.

Thene is little climatic datia available for the area. The climate is characterized by long cold winters and short warm summers. The average length of the frost-free period is approximately 90 days. Summer rainfall is low throughout the area.

The southern section of the region supports jack pine forests while the northern section supports black spruce forests. White birch forests are abundant in fire-disturbed regions that formerly supported black spruce foresits. A small aspen forest was present north of Stony Rapids.

The specimens reported in this collection can be found in the Canadian Wildlife Service Herbarium at Edmonton. Vascular plant specimens were sent to the Herbarium of the Canada Department of Agriculiture and moss and club moss specimens were given to the National Museum of Canada.

The author wishes to acknowledge the assistance of L. E. Erickson in the field. I am also grateful to Dr. H. A. Crum, to Dr. A. E. Porsild, and to the staff of the Plant Research Institute, Ottawia, for identifying or verifying the identification of the mosses, club mosses, and vascular plants, respectively.

\section{MUSCI}

Sphagnum capillaceum (Weiss.) Schrank-Higginson L. 368.

Sphagnum capillaceum var. tenellum (Schimp.) Andr.-Higginison L. 369. 
Andreaea rupestris Hedw.-Faraud L. 380.

Polytrichum commune Hedw.Higginson L. 395, Father L. 404.

Polytrichum juniperinum Hedw.Higginson L. 367, McKeever L. 377, 378 , and 379, Newnham L. 381 and 383.

Polytrichum juniperinum var. alpestro (Hoppe) BSG-Newniham L. 405.

Polytrichum piliferum Hedw.Higginson L. 370, Oblate L. 371 and 374, Newnham L. 382.

Ceratodon purpureus (Hedw.) Brid.-Higginson L. 370, Oblate L. 371, 372, and 373, McKeever L. 375 and 386, Oblate L. 388.

Pleurozium schreberi (Brid) Mitt.

- Higginson L. 380 and 394.

Dicranum elongatum Schleich.Grove L. 397.

Dicranum rugosum (Hoffm.) Brid. - Higginson L. 393. 402.

Hedwigia ciliata Hedw.-Father L.

Aulacomnium palustre

Schwaegr.-Father L. 403.

Ptilium crista-castrensis (Hedw.)

DeNot.-Grove L. 398.

Neckera pennata (L.) Hedw.Faraud L. 384.

\section{HEPATICAE}

Ptilidium ciliare (L.) Nees-Higginson L. 392, Grove L. 394, Newnham L. 406.

Marchantia polymorpha L.-MicKeever L. 376, Faraud L. 385.

\section{POLYPODIACEAE}

Woodsia ilvensis (L.) R. Br.-Dry rocky area. Flaraud L. 535.

Dryopteris disjuncta (Ledeb.) C. V. Morton-Collected below a seepage area on a rock slope. Grove L. 445 .

Dryopteris fragrans (L.) Schott.Found on exposed rock ouitcrop. Chipman L. 611.

Cryptogramma crispa (L.) R. Br. var. acrostichoides (R. Br.) C. B. Clarke-Rare plant on rocky slopes. Higginson L. 422, Marchant L. 599.

\section{EQUISETACEAE}

Equisetum sylvaticum L.-Common $\therefore$ recent burns. McKeever L. 506.

亡. isetum sylvaticum L. var. multiramosum (Fern.) Wherry-Common on moist areas in recent burns. Oblate L. 485.

Equisetum fluviatile L.-Common in marshes and along lake shores throughout area. Oblate L. 400, McKeever L. 513, Dodge L. 602, Chipman L. 622 .

Equisetum scirpoides Michx.Found in bcggy black spruce sites. Faraud L. 511.

\section{LYCOPODIACEAE}

Lycopodium annotinum L. var. pungens (La Pyl.) Desv.-Occasional in black spruce forests. Higginson L. 389 and 391.

Lycopodium obscurum L.-Infrequent on recent burns. Little Faraud L. 401.

Lycopodium complanatum L.-Frequent in young birch stands. Oblate L. 387, Higginson L. 395, Faraud L. 400 .

\section{PINACEAE}

Picea glauca (Moench) VossFound only along the Fond-du-Lac River near Stony Rapids and a few representatives at Faraud L. and Black L.

Picea mariana (Mill.) BSP-An ubiquitous tree on upiand and muskeg sites.

Larix laricina (Du Rci) KoshCommon in muskegs thrcughcut area. Grove L. 439.

Pinus banksiana Lamb.-Abundant on sandy soils south of Black L.

Juniperus communis L. var. depressa Pursh-On sand soils in cpen areas. Grove L. 443.

\section{GRAMINEAE}

Festuca saximontana Rydb.-Rcadside collection. Stony Kapids 567 .

Poa pralensis L. - - vrfoist ar aas near lakes. Oifset L. 476, Stcny Kapids 516.

Poa interior Rydb.-On open rocky outcrops. Fauaud L. 533, Doage L. 600 .

Poa palustris L.-Townsite collection. Sitony Rapids 555.

Poa glauca Vahl-Infrequent in recent burns and in mature birch stands. Grove L. 427, vlckeever L. 502.

Agropyron trachycaulum (Link) Malte-Kare in townsite of Sicny Rapids 562.

Hordeum jubatum L.-Abundant in near old camp sites along Fonddu-Lac River. Stony Rapids 560 and 561.

Deschampsia caespitosa Beauv.-Along moist road side. Stony Rapids 566. 
Calamagrostis purpurascens $\mathrm{R}$. Br. - Rare on sandy ridge. Dodge L. 605.

Calamagrostis canadensis (Michx.) Beauv.-Abundan't on recent burns through area. Oblate L. 496. Little Faraud L. 522, Stony Rapids 557.

Agrostis scabra Willd.-Common in moist areas and on recenit burns. Little Faraud L. 527, Faraud L. 534, Stony Rapids 556.

Alopecurus aequalis Sobol.-Common along moist road side. Stony Rapids 565 and 573.

Beckmannia syzigachne (Steud.) Fern.-Wet area near road side. Stony Rapids 580.

\section{CYPERACEAE}

Eriophorum spissum Fern.-Infrequent in moist muskeg site. Offset L. 452.

Eriophorum angustifolium Honck. -Infrequent in moist muskegs. Stony Rapids 550.

Scirpus caespitosus L. var. callosus Bigel.-Moist site near lake shore. Faraud L. 538.

Scirpus hudsonianus (Michx.) Fern.-Lake shore collection. Faraud L. 537.

Carex foenea Willd.-Along sandy beach margins. Higginson L. 415.

Carex siccata Dewey-Found on a sandy beach at Dodge $L$. and in dry birch forests. Stony Rapids 584, Dodge L. 604, Father L. 607.

Carvex loliacea L.-Infrequent in mature birch stands. Oblate L. 487, Faraud L. 547.

Carex brunnescens (Pers.) Poir.Infrequent in moist areas. Grove $L$. 447, Oblaite L. 473.

Carex canescens L.-Abundant on the edge of muskegs throughout the area, also occurred on recent burns. Offset L. 455, McKeever L. 508, Little Faraud.L. 530, Stony Rapids 585.

Carex aenea Fern.-Abundant carex on recent burns. Oblate L. 477, Little Faraud L. 524, Newnham L. 615.

Carex deflexa Hornem.-Common on recent burns throughout area. Grove L. 426 and 435, Oblate L. 486, Dodge L. 601.

Carex paupercula Michx.-Muskeg areas in region. Offset L. 461, Oblaite L. 482 .

Carex media R. Br.-Moist areas in black spruce forests. Oblate L. 488, Faraud L. 539.

Carex aquatilis Wahl.-Widely distributed in marshes throughout area. Offset L. 456 and 462, Mc-

Keever L. 498, Faraud L. 540.

Carex rostrata Stokes-Common on boggy areas. Stony Rapids 551 and 579 .

\section{JUNCACEÂE}

Juncus vaseyi Engelm.-On the margins of muskegs and bogs. Stony Rapids 549 and 587.

Juncus balticus Willd.-Located on sandy shore. Newniam L. 617.

Luzula multiflora (Retz.) Lej.Rocky island in McKeever L. This collection extends the known northern range in Saskatchewan. McKeever L. 514.

\section{LILIACEAE}

Smilacina trifolia (L.) Desf.Rare in wet black spruce muskegs. Oblate L. 446.

\section{ORCHIDACEAE}

Spiranthes romanzoffiana Cham. \& Schl. - Rare in wet black spruce bogs. This record is an extension of the northern range in Sask. Stony Rapids 597.

\section{SALICACEAE}

Populus tremuloides Michx.-Scattered individuals throughout area except for a large stand near Sitony Rapids.

Populus balsamifera L.-Infrequenit on wet ground near lake shores. Grove L. 438.

Salix glauca L.-Frequent throughout region in muskeg and other moist sites. Higginson L. 420, Offset L. 453 and 460, Oblate L. 479 and 494 .

Salix myrtillifolia Anderss.-Frequent in black spruce forests and in young birch forests throughout the region. Higginson. L. 421, Grove L. 431, Faraud L. 520.

Salix? pseudomonticola Ball-Rare along streams in mature birch forests. Oblate L. 489.

Salix pyrifolia Anderss.-Found in recent burns and in moist forests. Grove L. 432 and 437B, Offset L. 471.

Salix bebbiana Sarg. - The largest willow found in the area. Infrequent in black spruce forests. Oblate L. 475.

Salix planifolia Pursh-Frequent along streams and lake edges. Offset L. 470, Faraud L. 536.

Salix arbusculoides Anderss.Common willow on the margins of streams and lakes. Offset L. 459, McKeever L. 500. 


\section{MYRICACEAE}

Myrica gale L.-Abundant on the margins of lakes and muskegs throughout region. Offset L. 469, Oblate L. 493, McKeever L. 501, Dodge L. 603.

\section{BETULACEAE}

Betula papyrifera Marsh-Abundant as a seral stage in burnt areas. Higginson L. 423.

Betula papyrifera Marsh var. resinifera (Regal) Fern \& Raup-Associated with mature black spruce forests. Grove L. 437A.

Betula papyrifera Marsh var. humilis (Regal) Fern. \& Raup-Ccmmon on recent burns. Higginson L. 412.

Betula glandulosa Michx.- Rare in forests and frequent in muskegs. Grove L. 436, Offset L. 454 and 468, Oblate L. 484.

Alnus crispa (Ait.) Pursh-Abundant on south slope in black spruce and jack pine forests. Higginsion $\mathrm{L}$. 419 , Offset L. 467.

Alnus tenuifolia Nutt.-Abundant along the Fond-du-Lac River. Stony Rapids 608.

\section{SANTALACEAE}

Geocaulon lividum (Richards) Fern.-Common throughout area, but most abundant in jack pine forests. Offset L. 466, Faraud L. 512, Sitony Rapids 595.

\section{POLYGONACEAE}

Rumex occidentalis S. Wats.-Infrequent along roadside. Stony Rapids 581.

\section{NYMPHAEACEAE}

Nuphar variegatum Engelm.Abundant in sheltered lakes and streams throughout area. McKeever L. 504 .

\section{RANUNCULACEAE}

Anemone patens L. var. multifida Pritzel-A rare plant found only on grassy slopes near fishing camps. Black L. 407.

Ranunculus lapponicus L.-Rare in mature birch stands that occur along stream channels. Grove L. 448, Faraud L. 541.

Ranunculus abortivus L--Rare in mature birch stands that occur near streams. Stony Rapids 576.

\section{FUMARIACEAE}

Corydalis sempervirens (L.) Pers. -Frequent plant in recent burns. Grove L. 441.
Corydalis sempervirens (L.) Pers. f. candida Lakela-Frequent in burnt areas. Oblaite L. 478.

\section{CRUCIFERAE}

Draba nemorosa L.-Dry grassy slopes. Black L. 408. Stony Rapids 569.

Lepidium bourgeauanum Thell.A common weed in the townsite. Stony Rapids 554.

\section{SAXIFRAGACEAE}

Saxifraga tricuspida Rottb. - Infrequent on rocky ridges. Grove L. 425, McKeever L. 503.

Ribes oxyacanthoides L.-Infrequent on rocky hillside. Chipman L. 610 and 623.

Ribes hudsonianum RichardsonInfrequent in a mature white spruce forest near the Fond-du-Lac River. Stony Rapids 609.

Ribes glandulosum Grauer-Common on burnit areas. Grove L. 442, Oblate L. 480, McKeever L. 505, Little Flaraud L. 526.

\section{PARNASSIACEAE}

Parnassia palustris L. var. neogaea Fern. (P. obtusiflora (Rupr.) E. M. Love)-Mcist black spruce fcrest sites. Stony Rapids 571, Newnham L. 612 .

\section{ROSACEAE}

Amelanchier alnifolia Nutt.-Collected in an aspen forest north of the Fond-du-Lac River. Stony Rapids 588.

Rubus idaeus L. var. aculeatissimus Regel \& Tiling-Common on recent burns and frequent in mature birch forests. McKeever L. 499 and 509, Faraud L. 545.

Rubus chamaemorus L.-Common in muskegs. Higginson L. 417, Offset L. 472 .

Rubus acaulis Michx.-Frequent on moist black spruce and birch sites. Oblate L. 491, Stony Rapids 586.

Fragaria vesca L.-Roadiside collection. This collection extends the northern range of this plant in Saskatchewain. Stony Rapids 575.

Potentilla norvegica L.-Common in disturbed areas. McKeever L. 515, Stony Rapids 553 and 577, Dodge L. 606, Chipman L. 621.

Potentilla palustris (L.) Scop.Infrequent in moist aspen and black spruce forests. Grove L. 444, Stony Rapids 592.

Potentilla tridentata Ait.--Infrequent on rock outcrops and on recent 
burns. Stony Rapids 594, Newnham L. 616 .

Geum perincisum Rydb.-North slope near Fond-du-Lac River. Stony Rapids 583.

Rosa bourgeauiana .Crep.-Common along ditch banks. Stony Rapids 572.

Prunus pensylvanica L. f.-Frequent on dry hillsides. Little Faraud L. 523, Faraud L. 522 .

\section{EMPETRACEAE}

Empetrum nigrum L. var. hermaphroditum (Lange) Sorensen-Common on sphagnum moss throughout the black spruce forests in this region. Higginson L. 418.

\section{ELAEAGNACEAE}

Shepherdia canadensis (L.) Nutt. -Infrequent in moist areas. Stony Rapids 598.

\section{ONAGRACEAE}

Epilobium angustifolium L. (Chamaenerion angustifolium (L.) Scop.)Ubiquitous on burnt areas. Little Faraud L. 525.

Epilobium glandulosum Lehm. var. adenocaulon (Haussk.) Fern.-Raup reported this plant common in sloughs and weit meadows, but it was only collected on a dry hillside. Little Faraud L. 529.

\section{ARALIACEAE}

Aralia nudicaulis L.-Frequent in aspen forests. Stony Rapids 596, Black L. 624.

\section{CORNACEAE}

Cornus canadensis L.-Frequent in open black spruce and jack pine forests. Stony Rapids 559.

\section{PYROLACEAE}

Moneses uniflora (L.) A. GrayFrequent in moist black spruce sites. Faraud L. 543.

Pyrola secunda L. (Orthilia secunda (L.) House)-Frequent in moist birch and muskeg sites. Faraud L. 521 and 548 .

Pyrola virens Schweigger-Rare in moist birch forests. Faraud L. 542.

Pyrola asarifolia Michx.-Infrequent in aspen forests north of the Fond-du-Lac River. Stony Rapids 593.

\section{ERICACEAE}

Ledum groenlandicum OederAbundant throughout region. Offset L. 449.

Ledum palustre L. var. decumbens Ait.-Infrequent on exposed cliffs and rocks in black spruce forests, but not present in muskegs as reported by Raup. Grove L. 428 and 440 , Offset L. 464.

Loiseleuria procumbens (L.) Desv. - Rare on a dry. open site above a muskeg. This plant is new to the flora of Saskatchewan. Little Faraud L. 531 .

Kalmia polifolia Wang.-Abundant in muskegs. Grove L. 429, Oblate L. 483.

Andromeda polifolia L. - Abundant in muskegs. Higginson L. 413, Grove L. 429.

Chamaedaphne calyculata (L.) Moench-Frequent allong lake shores and in muskegs. Higginson L. 414. Offset L. 463, Little Faraud L. 528 .

Arctostaphylos uva-ursi (L.), Spreng.-Common on sandy hillsides in jack pine forests. Black. L. 409.

Vaccinium uliginosum L.-Common in moist areas near muskegs and lakes. Offset L. 458 and 465 .

Vaccinium myrtilloides Michx.Abundant in jack pine forests. Offset L. 457, Newnham L. 618 and 620 .

Vaccinium vitis-idaea L. var. minus Lodd.-Abundant in muskegs and on dry upland sites. Black L. 410 .

Vaccinium oxycoccus L.-Infrequent on moss in west muskegs. Offset L. 450 .

\section{MENYANTHACEAE}

Menyanthes trifoliata L.-Common in shallow water near lake margins. Oblate L. 476, Faraud L. 518.

SCROPHULARIACEAE

Pedicularis labradorica WirsingRare in muskegs. This is a new addition to the flora of Saskaitcherwan. McKeever L. 510 .

\section{LENTIBULARIACEAE}

Pinguicula villosa L.-Rare on sphagnum moss in muskegs. Offset L. 451 .

\section{RUBIACEAE}

Galium trifidum L.-Infrequent in moist birch stands. Faraud L. 544 .

\section{CAPRIFOLIACEAE}

Viburnum edule (Michx.) Raf.Infrequent near streams in birch stands. Oblate L. 492.

Linnaea borealis L. var. americana (Forbes) Rehd.-common on sandy soils in jack pine forests. Grove L. 424.

Campanula rotundifolia L.-Common throughout townsite. Stony Rapids 582 . 


\section{COMPOSITAE}

Solidago spathulata DC.-Rare in opening of an aspen forest north of Fond-du-Lac River. Thiis extends the known northern range in Saskatchewan. Stony Rapids 591.

Aster laevis L.-Roadside collection. This plant was reported at McMurnay, Chipewyan and L. Mamawi by Raup. This collection extends the range into nonthern Saskatchewan. Sitony Rapids 574.

Aster ciliolatus Lindl.-Rare in moist areas of a mixed black spruce and jack pine forest. Stony Rapids 570.

Achillea sibirica Ledeb.-Rare on a rock outcrop. This collection is a northern extension of the known range in Saskatchewan. Newnham L. 613.

Achillea lanulosa Nutt.-Roadside collection. Stony Rapids 558.

Matricaria matricariodes (Less.) Ponter-Common on abandoned campsites. Stony Rapids 564.

Petasites palmatus (Ait.) A. Gray -Infrequent on moist areas. Oblate L. 481, McKeever L. 507.

Petasites vitifolius Greene-Common in townsite and along road ditches. Stony Rapidis 578.
Petasites sagittatus (Pursh) A Gray-Rare in moist areas of a birch forest. McKeever L. 497.

Senecio pauperculus Michx. var. flavovirens (Rydb.) Boivin - Infrequent in an aspen forest north of the Fond-du-Lac River. Stony Rapids 589.

Taraxacum dumetorum GreeneRare on a rocky island. McKeever L. 517 .

Taraxacum officinale Weber Common in the townsite. Stony Rapids 553.

Hieracium scabriusculum, Schwein. - Infrequent on rock outcrops and in aspen forests. Stony Rapids 590, Newnham L. 614.

\section{LITERATURE CITED}

Alcock, F. J. 1936. The Geology of the Athabaska Region. Geol. Surv. Canada. Memoir 196. 1-41.

Bnietung, A. J. 1957. Annotated catalogue of the vascular flona of Saskatchewan. Amer. Mid1. Nat. 58:1-72.

Fraser, W. P., and R. C. Russe11. 1954. An annotated list of the plants of Saskatchewan. Univensity of Saskatchewan, Saskatoon, Sasklatchewan. 1-47.

Preble, E. A. 1908. A biological investigation of the Athabaska-MacKenzie region. U.S. Dept of Agric. No, 27. 1-574.

Raup, H. M. 1936. Phytogeographic studies in the Athabaska-Great Slave Lake region. Jour. Arn. Arb. $17: 180-315$ pp.

Tyrrell, J. W., 1908. Across the sub-arctics of Canada. William Briggs, Toronto. 1-280.

\section{Large-flowered Hemp Nettle}

(Galeopsis speciosa)

\section{by E. H. Moss, Edmonton}

Many readers of the Blue Jay are doubtless acquainted with the Common Hemp Nettle, Galeopsis tetrahit, an introduced weed of waste places, roadsides and fields. Perhaps few know that it is of hybrid origin, the parent species being $G$. pubescens and $G$. speciosa. This was shown some thirty years ago by Muntzing in Sweden. By crossing the two parent species Muntzing obtained a plant which, though highly sterile, was successfully back-crossed to G. pubescens. The latter cross gave a fertile plant which was indistinguishable from $G$. tetrahit, a species long known in nature.

The main purpose of this rote is to report the occurrence of Galeopsis speciosa, the Large-flowered Hemp Nettle, in Alberta. During the summer of 1960 specimens came to hand from two localities near Edmonton.
Dr. G. H. Turner submitted speciments collected near Fort Saskatchewan. From Mr. George Pegg came plants found near Heatherdown, some thirty miles northwest of Edmonton. The species is said to be prevalent at Heatherdown and to be spreading there. These collections appear to represent the first records of the species for Alberta, and possibly for Canada, apart from a collection made at Millet ( 30 miles south of Edmonton) in 1928. The latter collection, reported to the writer by Dr. C. Frankton, is in the herbarium of the Department of Agriculture, Ottawa. Dr. A. E. Porsild has informed Dr. Turner that there are no Canadian collections of the species in the National Herbarium, Ottawa.

The Large-flowered Hemp Nettle may be expected in ather parts of western Canada. Moreover, it may 